\title{
Post-Socialist Contradictions
}

\author{
The Social Question in Central and Eastern Europe and \\ the Making of the Illiberal Right
}

Don Kalb

Jan Breman and Marcel van der Linden have provocatively claimed that the Global South is coming to the North, rather than the other way around. ${ }^{1}$ Not "development" toward Northern modernity, but the informalization and flexibilization of the North, as in the South. They see the global economic agenda as hijacked by capitalist interests that seek the precariatization and stepped-up exploitation of the world's laboring populations. Global agencies duplicitously present this agenda as one of employment generation and poverty reduction-and therefore representing the "general interest." "Rigidities" stemming from the old language of labor cannot be allowed to derail this. The language of labor is a particularist trick on behalf of "rent seekers," "insiders," and "oligopolies of labor." The rhetoric of global institutions has perhaps been changing slightly since the financial crises of 20082014. Global economic technocrats consider social inequality now evidently as a negative. But the demand for "structural adjustment" and all that it entails in terms of precariatization and the flexibility of labor remains pervasive, from the IMF to the OECD to the ECB. And then there are "the markets" with their imperious judgments and their rejection of inflation. There is no reason to believe that a new era has arrived.

But as they are making this claim, Breman and van der Linden are sharply aware of differences and differentiations worldwide. There is no implication of global homogenization around a zero point of social dumping. But the overall direction they picture is globally shared, and it is useful that they state it without further ado. Until the recent revolt of "angry white labor" in the provinces-a symbol and figure of speech, of course, not a simple reality-social democrats and center-liberals of the "varieties of capitalism" school would certainly have responded to such a 
provocation with incredulity. Capitalism, in their vision, is an assortment of significantly diverging national varieties, to be chosen by major actors, not a unifying global historical complex with various systematically nurtured articulations. ${ }^{2}$ They will point to ongoing investments in "complex manufacturing" in new spaces, such as Brazil, Mexico, China, and central and eastern Europe. Such new spaces of "high-end" accumulation tend to be associated with upward regulation rather than any downward trends. One could also point to the Bolsa Familia in Brazil, the recent income-support schemes in India, and the officially sanctioned upward pressure on labor and social standards in China as other examples of opposite tendencies. $^{3}$ There is space for a more dialectical vision in their overall approach, of which they are aware. But, once more, it is useful that they state their main thesis of capitalist precariatization and social dumping straightforwardly.

Central and eastern Europe (CEE) has been powerfully re-industrialized in the years after 1995, though unevenly. It now serves as the premier mass-manufacturing site for the European Union and hosts various branches in transnational services such as call centers, retailing, media, software, and finance. The "Visegrad countries" of north-central Europe, plus Slovenia, have been reintegrated into western European-above all, German-supply chains. The Czech Republic, Slovakia, and Hungary are now more open to trade and are more export-dependent than they ever were before and more so than most western countries. Until the mid-20oos they had also received broadly similar amounts of foreign direct investment per capita as China. With 70 percent of GDP generated through international trade, the smaller post-socialist countries close to the EU heartland now even beat historical champions of economic openness in the West such as Belgium and the Netherlands. They are proportionally among the top exporters worldwide, including in such branches as automotives and electronics. Since 2005, countries like Romania, Bulgaria, and Serbia have also acquired more complex manufacturing industries. The employment structures of the "successful" CEE countries therefore tend to be more industrial than those of western or southern Europe, with around 30 percent of the labor market in manufacturing. So, against this background, what about Breman and van der Linden's universal precariatization thesis?

\section{THE VIOLENCE OF A TRANSITIONAL RECESSION WITH MERE SHALLOW POVERTY}

By 2000, the Visegrad countries (Poland, Hungary, the Czech Republic, and Slovakia) and the Baltics were slowly extricating themselves from what experts in "transition economics" (a deeply neoliberal field) had disingenuously called the "transitional recession." That so-called transitional recession-the name suggests ephemeral qualities - was, in reality, the largest, most devastating and protracted social crisis that any part of the modern world had ever experienced. Greece after 
2010 comes close in purely economic terms, but aggregate economics was only a part of the post-socialist crisis, and Greece did so at a much higher level of wealth. There had been an average reduction of real wages with around 30 percent, followed by a long stagnation of median incomes; consistently high inflation of basic prices; a durable reduction of formal employment of some 20 percent across the board; and a slide of real GDP anywhere between 20 percent and 50 percent.

This economic devastation coincided with a fundamental restructuring of social relationships and social institutions; a swift dwindling of state power and authority; ongoing panic about "the law" and security; the threat of open, collective violence in many places, serious social and cultural tensions everywhere, and actual civil wars in the least fortunate spaces; dramatic reversals in male mortality, as males died from alcohol and the cold; and even, over time, declines in literacy. In the more "successful" post-socialist countries, those losses would be evened out sometime between 2000 and 2008 ; others had to wait a decade or more. Just when some modest optimism was emerging, the Wall Street and Euro crises caused serious hits. ${ }^{4}$ It was no wonder that the new governing elites in CEE in the early 1990 s had been terrified that the liberal transition they were overseeing might be undone by popular rage.

In the early 1990s, two broad social policy designs resulted from those elite fears for popular havoc: (1) Relatively generous pension and disability benefits for people above fifty years old, meant to cushion mass redundancies; and (2) unemployment and family benefits, much less generous, to help younger working families stay out of absolute poverty. ${ }^{5}$

With some initial exceptions - the Czech Republic, Slovakia, and Romaniamost countries settled on a dual policy path combining fast economic liberalization and privatization with a flanking social policy to cushion the mass exit from the labor market and forestall destitution and mass revolts. By the late 199os the upshot for labor had become clear. (1) A massive reduction in formal employment throughout the region from some 70 percent to 50 percent of the working population. (2) Consistent medium to high levels of unemployment (in Poland, for example, the level was 18 percent for roughly a fifteen-year period). (3) The stabilization of median wages at a very low level that endangered family social reproduction (fertility declines everywhere). Prices rose quickly to western European levels. Apart from Slovenia and the Czech Republic, median wages were stuck anywhere between two hundred and five hundred euros per month even by 2015, despite two decades of economic growth. (4) There was a proliferation of informal forms of social reproduction, including migration (circular, seasonal, and definite), selfprovisioning, petty entrepreneurship, moonlighting, and double and triple jobs. (5) The spread of complex practices of income pooling within domestic groups, households, and kinship networks, including the income from public transfers such as pensions and social benefits. (6) The labor market had become radically deregulated in practice. (7) Politics was characterized more by "exit" and voting 
with the feet than by "voice." Electoral participation hovered generally around a low 50 percent.

Taken together, these downward spiraling processes were inevitably leading to the making of substantial relative and absolute surplus populations, in particular outside metropolitan spaces. The Roma were among the most identifiable of victimized groups. The sheer duration and extent of their poverty inevitably produced sharp segregation; illicit economies; violence; harsh competition for space, work, and benefits; ethnicization; and the predictable moral panics among local working and middle classes, including raw political attacks.

But it has always been deeply misleading to equate social expendability in CEE with visible ethnic markers - the liberal "transition lie" par excellence. Large populations in the provinces all over CEE, even in the Czech Republic, were turned into semi-surplus populations and ostensibly written off. Many poorly educated people in CEE found themselves durably caught in a poverty and precarity trap, particularly those in regions that were locked into long-term spirals of decline. Many people felt squeezed between those with access to the few good jobs and a hold over local politics, on the hand, and the ethnicized absolute surplus populations on the other. In some areas in the 1990s, a majority of actually employed or self-imagined working people, the working poor, were coping with household income levels around two hundred to three hundred euros per month and were structurally dependent on benefits, remittances, and in natura support from kin. The household surveys done by a team of urban geographers led by Alison Stenning in Nowa Huta, Poland, and Petrzalka, a suburb of Bratislava, show that this was true even for households in the boom cities of the mid-20oos, as well as when local unemployment was very low. ${ }^{7}$ In those relatively well-off urban neighborhoods, if your education was poor or of the wrong type, and if you had young children, you were very likely to be in structural poverty. Existential insecurity was widespread. This was the case amid economic growth and ostentatious consumption by the few and in a context where politicians were more interested in pointing at the latter than caring about the former. In the absence of a credible left, this would come to haunt the region in the form of a slowly building politics of anger and resentment.

POLARIZING SOCIETY, FUELLING CULTURE TALK:

THE CLOCKWORK OF HIERARCHY

Why did labor fail to defend itself against the neoliberal onslaught? This has understandably been a key question in the literature. Most authors have resorted to a "labor weakness" explanation. ${ }^{8}$ But if labor was indeed so weak, where did its weakness lie or come from? Was it weak on the shop floor, in the national public sphere, in post-socialist ideology? Scholars have pointed to subdued labor unions under socialism, unions that were mere parts of the administrative apparatus, with 
no experience of mobilization-but in Poland, the opposite was the case. Other authors have pointed to the negative ideological reputation of class politics and labor rhetoric after socialism. I have come to doubt the intuitive validity of these answers. My own answer has emphasized that labor was sometimes surprisingly strong on the shop floor, often decidedly stronger than in the West, but not so on the national level-either within the bargaining structure of "tripartism" or on the level of public ideas. While labor was not a unified national force, it was an important local factor in many places, in companies, and in local politics. Every weakness it had seems to have emerged from the disconnect between those levels.

More fundamentally, the weakness of post-socialist labor, I have claimed, was a "weakness within."9 It sprang from the crumbling of socialist solidarity between those who stood to gain from capitalism and were-amid stagnation and serious economic threats-hoping to finally get a fair price for their labor, and those who were seen as going to fail the test of the new value regime. In other words, in anticipation of capitalism's coming, labor fractured between the skilled, flexible, and efficient workers who had often formed the labor aristocracies of socialist production and those perceived as the spoilers of the coming efficiency drive. Thus, capitalism magnified and pushed into the open the status conflicts that had been obscured under socialism. It set a competition in motion, desired as well as real and inevitable, among the self-ascribed deserving and those they deemed undeserving, and it cracked open the always smoldering but repressed hierarchies of labor under socialism. It was this internal conflict within labor-fueled to the utmost by an intellectual state class that had made its reputation in the fight against socialism and, therefore, in the context of the global slide toward capitalist restoration, was always already liable to smoothly embrace neoliberal imaginaries-that ultimately explained the "emptiness" of labor as a political category.

Ethnographies have often reported of labor activists being jubilant about the coming fairness of the market. Labor organizers were certainly ready to advocate social protection for laid-off workers, and they were sometimes also ready to fight-hard-to defend local employment. But, avowedly, not for everyone. Annoyance about supposedly pervasive slacking often broke through. There was sometimes open satisfaction that those slackers were going to be punished. Ideologically, many workers tended to see the market as their opportunity to finally overcome an overbearing socialist mediocrity. The market was seen as the fair and transparent "culturally arbitrating" institution that would finally set them free from the socialist slackers, as well as from the socialist bureaucrats. ${ }^{10}$

The labor-weakness account is thus both problematic and more culturally complex than is usually assumed. A realistic relational approach should focus on those accelerating social cleavages and emergent hierarchies within labor itself. These served to disable collective action by workers as workers. A logic of de-solidarization was rolling through the region and transforming the potential collectivist politics of class into the myriad identity politics of culture and hierarchy. 
Jan Breman, writing about the global context, has recently called this the return of social Darwinism. The return of such social Darwinism in post-socialist Europe-a desire for a natural and meritocratically justified hierarchy-was not entirely unlike that in the West itself. But in CEE, it came in a pressure-cooker version in a peripheral and dependent capitalism that was going down the road of de-industrialization in the 1990 s much faster and much more pervasively so than anything seen in the West. Nor was there the compensation of fast growth in professional and consumer services characteristic of the metropolises of the core. The singular reality of CEE was the collapse of a full-scale urban industrial modernity-indeed, a labor-based and labor-driven modernity. After the collapse, only an uneven rebirth took place amid the culture-talk of deservingness and un-deservingness.

Such hierarchical desires emerging "from below" were magnified by a public sphere that was openly condescending toward common workers and peasants. The whole higher stratum of intellectuals and professionals in eastern Europe, including trade union experts and labor representatives themselves, stood to gain significantly from capitalist state making and market expansion, and they sensed it. Many of the leading intelligentsia and dissidents turned themselves from pro-labor advocates into aspiring state classes almost overnight, clamoring for the proliferating jobs and consultancies within the new central bureaucracies-administrations that, in fact, grew in numbers everywhere after socialism. The second echelon of apparatchiks and managers, meanwhile, were busy transforming themselves into the privatizers of assets that had belonged to the socialist commons or setting themselves up as political leaders. ${ }^{11}$

These social divisions became openly expressed in a new public vocabulary of cultural hierarchy from above. Intellectuals and professionals began to identify themselves boisterously as middle class and civil. Those just below desperately aspired to become part of that same enchanted circle. And all were impatiently awaiting the advent of a magical "Europe." Occidentalism took such a flight that, inevitably, the "East" became now often openly associated with an unsophisticated red-brown populist despotism of an imagined Asiatic type. While the new self-appointed middle classes were righteously claiming their place near or in the advanced West, their neighbors without such cultural elevation were expressly relegated to the supposed wastelands of the Orient. Rude Asiatic despotisms were seen as rightly befitting uneducated workers and peasants "who could not take care of themselves and were used to following orders"-Homo sovieticus types of persons. ${ }^{12}$ Their politics was seen as reflecting precisely this: unruly peasant and worker demonstrations were rejected as a form of uncivil and irresponsible "claiming behavior" that had to be rooted out. No respect for the subaltern here. Michal Buchowski has called this syndrome "internal orientalism." ${ }^{13}$

In such discourses, productivity and efficiency were not seen as abstract properties of national economies or production processes. Rather, they were perceived 
as deeply personal characteristics, key indexes of personal worth-thus organically anticipating and internalizing the tenets of the emergent neoliberalism. ${ }^{14}$ Those who failed to live up to the capitalist value regime, those literally described as the "losers of transition," were imagined to also dress, talk, and smell differently. And they were seen as only having themselves to blame. They were felt to be a dead weight on national productivity and dignity, a fifth column against the global success of newly sovereign and utterly deserving nations: traitors, embezzlers, slackers, hooligans, and drunkards. And it was felt that those who were now going to be surplus populations had always already been inappropriately shielded by "really existing socialism." Socialist rulers, it was said, had sought, unforgivably in the eyes of many, the alliance with the unruly and the unskilled, thus consigning their nations to an embarrassing mediocrity.

In a nutshell: what may have been crucial for the "defeat of solidarity" was how the local labor aristocracies felt about the less skilled. ${ }^{15}$ Labor aristocracies were essential for the running of socialist economies. ${ }^{16}$ These were rather tightly knit local working-class groups that were sometimes, as in Poland and Yugoslavia, de facto running the factories, including the associated social funds and affiliated labor unions and sports associations. By 1989 in Poland, they were sometimes even nominating their own directors on the managing boards, as had been commonplace in Yugoslavia. Also in Hungary or Romania, directors used to be "men of the people," since they could not rule without the people and, often, not so easily against them. But these core groups of workers were increasingly exposed to drastic economic pressure and the threat of total social failure. In this life or death economic context-a context of fear and ontological insecurity-they were not against turning the slackers and the unruly among the unskilled workers into a relative surplus population. My interviews with workers in Wroclaw in the late 1990 s were full of such thoughts, internal dialogues about the rightfulness of the impatiently awaited restoration of meritocratic hierarchy. Powerful capitalist pressures thus helped to unravel the possibility of solidarity among working classes upon which socialism as a form of rule had tenuously rested. The emergent informal capitalism of the $198 \mathrm{os}$, and then the quickly accelerating formal capitalism of the 1990s, cracked open the can of worms of repressed but visceral cultural hierarchy and inequality that state socialism had tried to compress and keep together against the odds.

The longer historical perspective is essential here. Socialism had installed itself in the first half of the twentieth century in a backward region. It was overwhelmed by this backwardness. In the absence of a "world revolution," Soviet socialism was, after 1923, pushed into political isolation by a vengeful West. "Socialism in one country" was incapable of escaping the logic of uneven and combined development in Russia, as well as later in central Europe. The low level of urbanization; the prevalence of large, undifferentiated, and underdeveloped agricultural spaces; the persistence of large post-feudal latifundia, semi-serfdom, debt peonage, and illiteracy-these were ominous starting points for a socialist modernization by 
and on behalf of workers and peasants. In the aftermath of Stalin's counterrevolution of 1928, agricultural collectivization, planned industrialization, and industrydriven urbanization were designed to overcome such backwardness. They were crucial for defeating Hitler. But the consequences of the prior underdevelopment, combined with the contradictions of socialist accumulation itself, put steady limits on what could be achieved. ${ }^{17}$

For one, socialism kept featuring a significant under-urbanization. Aggregate urbanization in the 1950 s and 1960s was fast, but it brought semiskilled industrial jobs to people in new provincial towns rather than concentrating both people and jobs in metropolitan centers..$^{18}$ Agriculture was at best only partly efficient. Scarcity regularly reappeared, and agricultural prices remained high. Sharp uneven development within the region, mostly going from west to east, was also never redressed. But even in the more advanced socialist urban districts in western areas, such as around Wroclaw (Breslau) or Györ-successful cities in the German and Habsburg Empires-a majority of workers in the local light engineering industries, even in the 1980s, would only have a primary school education. Commuting peasant workers were a large and economically essential category in socialist countries. Many urban households would share kitchens, toilets, and bathrooms. During the famous and funny Kitchen Debate between Nikita Khrushchev and Richard Nixon in 1959, Khrushchev had boasted that in ten years time Soviet workers would enjoy the same comforts as their American counterparts. Instead, after one more round of urbanization and industrialization in the early 196os, Eastern European socialism ran up against its limitations and would struggle for another twenty years-and ultimately, it would not undo those limitations but rather bury itself instead. It had produced an illiberal provincial industrialism of 1930s-1950s type. It was unable to switch, like the West, to an education- and consumptiondriven accumulation that would export its blue-collar jobs overseas and sweep up agricultural productivity.

So, in the context of the imposition of the capitalist value regime and the consequent fears and uncertainties, there were discourses of personal value, deservingness, and un-deservingness; cultural hierarchy; and "civilization" among common workers too, discourses that sought to separate the worthy from the unworthy. This was the powerful cocktail of forces (geostrategic, political, economic, social, cultural, and psychological) that served to silence, delegitimize, disorganize, differentiate, and then divide the eastern European working classes-despite their strong position on the local shop floor, despite high union membership, and despite sometimes very capable union leaders.

\section{NEOLIBERAL CONSOLIDATIONS: UNEVEN, COMBINED, CONTRADICTORY}

From 1998 to 2008, the post-Soviet world bifurcated into a set of unevenly neoliberalized and differentially transnationalized and financialized spaces. ${ }^{19}$ The 
question of labor and its relation with the illiberal Right is part of these territorial differentiations within one universalizing, capitalist space-making process. Relative distance to the operational core of capitalism in the West was a key differentiating property, changing with time. The social policy outcomes ranged from very neoliberal in the urban republics of the Baltics to much less so in social democratic Slovenia, though, over time, differences were evening out as the financial crises and austerity hit. ${ }^{20}$ Subsequently, the rise to power of illiberal populist forces in Hungary and Poland, and then elsewhere in the region, produced new differentiations in the direction of workfare and family benefits. Overall, integration into the European Union produced growth and reindustrialization as well as dispossession and disenfranchisement.

The average wealth outcomes, in fact, resemble pre-World War I positions visà-vis western Europe: Slovenia and the Czech Republic, once the most industrial parts of the Habsburg Empire, are now close to the EU average in wealth and productivity, on a par with Portugal and Greece (with some 50 percent to 60 percent of median incomes of "the West"); Hungary, Slovakia, and Poland remain below 40 percent. The rest of the region sticks to some 20 percent to 30 percent. Outmigration, the response to dispossession, was facilitated by the European Union and the Schengen agreements and has been substantial, significantly reducing unemployment in Poland, the Baltic republics, Romania, and Bulgaria, countries that now occupy top positions in the world out-migration and remittance rankings. ${ }^{21}$ All CEE countries have some 20 percent to 30 percent of GDP in the informal economy, making some households less poor in pecuniary terms than they appear on paper.

In a highly financialized and globalized environment, hard-pressed postsocialist states transformed into Schumpeterian "competition states." 22 In the competition to attract mobile capital, they began subsidizing foreign investments, reducing capital's tax bill, and putting downward pressure on wages and legal protections, all on behalf of international competitiveness.

In this context, social and economic policy outcomes were intensely contradictory. One tenacious path dependency from socialism seems to stand out: large constituencies never bought into the neoliberal idea that one is expected to simply take care of oneself. The notion that families with children, in particular, have a right to a minimal standard of social reproduction, including public health and education, is popular everywhere in CEE. ${ }^{23}$ What emerged, then, in the bargain between electorates and neoliberalizing states was the oxymoron of a quaint "neoliberal paternalism," an unstable compromise erected upon a fragile fiscal base geared to subsidizing transnational capital from the taxation of poor domestic labor.

Labor codes, for example, became increasingly neoliberalized over time, with the Polish and Slovak codes of the early 2000 s unleashing a wave of region-wide anti-labor regulations. Romania's 2013 labor code went perhaps the furthest in 
allowing unlimited hours, hardly any regulation of hiring and firing, hardly any legal redress - a code obscenely offered to lure foreign capital in the midst of the euro crisis. Global capital was consistently in favor of downward regulation of labor codes, domestic capital sometimes less so.

EU accession, thus, became a contradictory and confusing experience for labor. On the one hand, it appears that the acquis communautaire has helped to strengthen the de jure legitimacy of central bargaining and tripartism. But in reality, that tripartism remained overly weak. CEE states such as Poland and Romania kept a whole array of repressive legal measures in place against labor, including severe legal punishment of labor leaders if a strike was not first approved by a judge. The EU environment does help in singling out such measures for some public opprobrium. But policy competition among states to attract foreign capital, the deeper driver of the process, is all but hard-wired in the European Union and is further magnified in the CEE context. It has also driven the liberalization of the labor market below what was common even in the mid-199os. ${ }^{24}$

Policy competition also explains the dramatic slide toward an upwardly redistributional flat rate all over the region. Latvia introduced its flat tax of 13 percent in 1993, pushed through by a government of Latvian-American return-migrant entrepreneurs and libertarian adventurers. It spread soon through the Baltics and was copied by Slovakia in 2003 under Dzurinda's notoriously neoliberal catch-up government, which then caused a chain reaction. Almost overnight, Slovakia was turned into a world champion of export-driven car manufacturing - the introduction of the euro helped too, taking away foreign-exchange risk. By 2010 all CEE nations with the exception of Slovenia had introduced flat taxes. They are anywhere between 9 percent and 20 percent for both labor and capital, but rates for capital have been declining further. The actual taxation of capital has dwindled even below the nominal flat rates. There is little transparency on this, as everywhere else. The effective average taxation of capital in Hungary has been estimated at not more than 3 percent. ${ }^{25}$ Neoliberal paternalism is paid for by labor itself, including big subsidies for capital.

In spite of these downward pressures on the finances of CEE states, neoliberal governments have not succeeded in radically entrenching or privatizing the welfare systems that were introduced in the early 1990s, despite continuous advocacy to that effect by the World Bank and the European Bank for Reconstruction and Development. Without exception, post-socialist electorates refused to give up their public pension systems and family benefits; nor were they persuaded that privatized health would overall be good for them. Where such neoliberalizations were driven through, mostly by social democratic governments, large popular mobilizations emerged, often supportive of right-wing nationalist parties that condemned such policies. Populist right-wing governments in Poland and Hungary after 2010 have reversed earlier pension privatizations. In 2016 the Polish Law and Justice government drastically increased the benefits for families with children 
and lowered the pension age-defying the neoliberal current. The rise of "illiberal" right-wing governments, such as Orban's in Hungary and Law and Justice in Poland, is largely explained by the popular rejection of the dismantling of the post-socialist commons by neoliberal social democrats. Illiberal nationalist parties rhetorically and sometimes factually celebrate the protection and well-being of the working poor.

\section{CLASS STRUGGLE WITHOUT CLASS}

In the context of the defeat of Europe's labor-based modernity, Göran Therborn has posed a pertinent question about possible "class compasses" for the global twenty-first century. ${ }^{26}$ What sort of ideological frameworks might class struggle without class generate in the twenty-first century? Karl Polanyi's work perhaps suggests an answer. ${ }^{27}$ Polanyi wrote about "countermovements to protect society" against the planned imposition of transnational "free" markets (the "double movement"). In contrast to class movements, these could be on either the Left or the Right. He was writing with the central European experience of the interwar period as backdrop: fascism and Nazism. The "protection of society" against planned marketization in a context of class struggle without class can well take the form of the re-articulation of endangered "traditional" hierarchies. The post-socialist experience offers a contemporary illustration. In a first phase, dominant until the financial crises, neoliberalization and marketization are imposed in a "planned" way. In a second, the countermovements that emerged in the first phase become dominant, later even regionally hegemonic.

On closer scrutiny, this scheme is too neat. The phases are far less ontologically opposed in reality than the Polanyian reading suggests. Both phases of the double movement are, in fact, about creating social hierarchies. But they do so differently and with a different ideology. The neoliberal marketization phase invited a strong undercurrent of consent from the upper segments of labor, as from the governing elites, who wanted to believe that their desires for a deserved meritocratic hierarchy would be realized through fair markets. The second, illiberal phase, can be understood as emerging out of the realization among common people and workers, as well as provincial bourgeoisies, that this supposed association of markets with meritocratic fairness is an illusion. Hence, in the 1990s, there was the tenacious public narrative in the region that real capitalism never arrived, that it was always already corrupted by former communists or the secret services now playing the democratic game. In the next phase, an authoritarian state was now brought in to reassert the interests of deserving working families and provincial bourgeoisies.

In fact, we have, then, two contemporary varieties of social Darwinism. Both are striving toward a justified natural hierarchy, the first through markets and efficiency, the second through protective nationalist states. The first is a neoliberal Darwinism; the second, a national-socialist (stricto sensu) Darwinism. These 
varieties do not represent a hard bifurcation or opposition. Both seek a hierarchy and support the market, though the first trumpets the global market and cosmopolitanism and employs a liberal state machine, and the second embraces nationalist regulation and illiberalism. They are, then, two observable strains within one broadly right-wing thread, one seeking economic inequality, the other cultural hierarchy, to coin a phrase.

Neoliberal Darwinism is primarily middle-class driven and cosmopolitan, in factual as well as imaginary ways, though it does gain substantial working-class consent for a while. It deploys notions of meritocratic hierarchy interwoven with a glorification of capitalist discipline and efficiency against poorer and weaker classes of citizens, and it is ready to turn such citizens into undeserving surplus populations.

The national-socialist variant may also be middle-class driven but is more provincial, rather lower-middle class, literally and stylistically. It rhetorically cherishes the deserving national working classes, which are strictly separated (symbolically, ritually, and in policy) from the undeserving segments. Indeed, it needs and summons deserving workers as a vital and mobilized electoral constituency. It projects a protection of deserving working members of majority ethno-nations against a greedy and disloyal cosmopolitan capitalism, on the one hand, and the "criminal" classes dangereuses, the surplus populations, on the other. ${ }^{28}$ Both strains, the neoliberal as well as the national-socialist, are driven by the politics of class struggle without class and articulate a vindictive politics of culture and hierarchy.

How did the rise of illiberalism unfold within CEE? Hungary has served as a laboratory for the national-socialist form: a right-wing super majority that allowed for a new constitution and the construction of an illiberal state with universal welfare rights definitively switched off. It was first driven by the rise of a radical faction organized around the Jobbik party. This radical right-wing party flirted openly with paramilitary exercises in Roma settlements, the harassment of NGOs, and a pro-Putin-even pro-Iran-foreign policy, all combined with a rhetorical attack on foreign finance, foreign capitalists, the European Union, and the "plebeian" enemies: the ethno-nation, immigrants, and the Roma. The Polish Right does not march far behind. It features a stronger labor-contingent than the Hungarian Right and has accordingly claimed stronger positions on child benefits, family benefits, and pensions. With this program, it won the Polish presidential and parliamentary elections in 2015. Taking programmatic inspiration from Orban's illiberal revolution in Hungary, it is similarly disposed against the Roma, migrants, Muslims, gays, Jews, transnational capitalists, and the European Union (though it is ready to arm itself against Putin's Russia and is decidedly more misogynistic than Jobbik). Putin himself has mobilized the Russian workers of the provinces in an illiberal alliance against the big cities, the gays, the NGOs, and the West. He purposefully marshaled them against the "creative classes" of Moscow and other big cities who rallied against his usurpation of power in 2011-2012. In Slovakia, 
Romania, and Ukraine, waves of public attention to issues of deservingness/undeservingness have focused on majority/minority relations, often mobilizing the nation against poor Roma (if and where they have been "available" for such purposes) or finding others to take the place of the Roma-from Jews and gays to communists (the Polish and Ukrainian Right). ${ }^{29}$

In contrast, the Baltics have produced a strong vernacular neoliberal Darwinism. These countries have again turned into city-states, singularly dominated by foreign finance, real estate, entrepreneurial "creative classes," and associated inputs into higher education. Russian speakers, located in the mining provinces close to the Russian border, have been seen as the cultural fifth column. ${ }^{30}$ Russian-speaking miners are the local substitute for the Roma.

The Bulgarian experience of 2013 shows how shifty the class bases and orientations of these angry populisms can be. During a cold February, a nationalistprotectionist uprising in the provinces, driven by "common Bulgarian people" protesting against poverty and the high cost of basic utilities-privatized to transnational capitalists-led to the immediate abdication of a neoliberal right-wing government. The post-socialist social democrats won the subsequent election but made (characteristic) errors with personnel choices. They were immediately confronted with a months-long Sofia-based "Bulgarian middle-class" mobilization, kept up day after day over the summer, seeking to keep the nation out of the hands of the "red oligarchs and their alliance with the uneducated poor." It claimed that Bulgaria had to be run on behalf of "the productive Bulgarian bourgeoisie" and not for "the parasites on welfare." Protestors in Sofia literally demanded "quality versus quantity." ${ }^{31}$ For a taste of context, it might be added that in Bulgaria-the European Union's poorest nation-85 percent of income was spent on basic necessities, including utilities. A local journalist remarked dryly that the Bulgarian "productive middle classes" who were protesting in Sofia, and who were supposedly beyond such dire straights, earned, on average, not much more than four hundred euros a month, far below any poverty line in the West of the continent. The outcomes of elections in both Bulgaria and Romania in late 2016 suggest, further, that the national-socialist politics of class without class in southeastern Europe might, in contrast to Poland and Hungary, be carried forward by social democratic parties.

\section{LABOR, POLANYIAN COUNTERMOVEMENTS, AND \\ THE MAKING OF THE ILLIBERAL VISEGRAD BLOC}

Most westerners first learned about the "Visegrad Bloc" in late 2015 as it loudly refused to share in the reallocation of Middle Eastern refugees over EU space. The bloc, driven by the avowed "illiberal democracies" of Hungary and Poland, was adamantly nationalist, celebrated its national cultures as European fines fleures, and declared that it would defend these national cultures and, indeed, Europe itself against a multicultural, cosmopolitan European Union. 
The Visegrad Bloc, however, was not at all new. It had existed as a formal collaboration between Poland, Hungary, Slovakia, and the Czech Republic from 1993 onward. But as CEE states turned into neoliberal competition states to lure global capital away from each other, there was little to discuss among them. Synchronization worked on automatic pilot toward a low point of neoliberalization and social dumping. National-socialist (stricto sensu) mobilizations-first in Poland in the early 2000s, then in Hungary after 2006, and again around the elections in Poland in 2015 and in Slovakia in 2016-transformed this bloc into a boisterous illiberal affront against a cosmopolitan European Union. ${ }^{32}$ Neoliberal cosmopolitanism was meeting its "other" in neo-nationalist electoral mobilizations driven by the politics of class without class, endorsed by the "white working classes" of the provinces.

As I have argued, we need to place the dynamics of the bloc's making squarely within the relationships between capital, states, labor, and the politics of value. While this is not the place to work this out in detail, ${ }^{33}$ here is a basic outline, offered as a coda.

First, an elite campaign of public condescension of workers and peasants took place in the 1990s. The "illiberal revolution" should be understood as the popular and populist counterpunch. Now the symbolic East had found its voice and spoke back in a biting tone against civil society and other idols of the 199os. The rise of illiberalism was the political outcome of the making of the "eastern scale." I use this as a metaphor for the "orientalized" losers of the transition, as well as a reference to the geographic location where they assembled their critical mass - an electoral bloc of the self-declared disenfranchised of the poor eastern provinces, just as the Visegrad Bloc itself assembles the "eastern scale" for the European Union as a whole. The illiberal transformations in CEE are driven by electoral mobilization processes in the east of the East, in eastern Hungary, eastern Poland and eastern Slovakia-in other words, in those territories where the social reproduction of labor has stagnated more lastingly than in the new industrial spaces in the western manufacturing corridors and around the capital cities. They express the unevenness of capitalist dynamics - the stagnation, humiliation, and disempowerment of wide strata of labor-and the spread of relative and absolute surplus populations.

Second, the "eastern scale" came into its own as a veritable Polanyian countermovement. It reacted against transnational marketization and the social abandonment associated with the "competition state" syndrome. It emerged as a classical Polanyian "protection of society," substituting itself for the absent capacity of labor to confront capital and the state directly.

Third, this Polanyian countermovement came in three phases. The first phase played itself out in the late 1990 s and early 2000 s in Poland and was labor driven. Constituencies with a history of radical confrontation with the state-first in the context of Solidarnosc and later in the context of privatization, transnationalization, and consequent neoliberal dispossessions and disenfranchisements-developed 
an organic angry politics of resentment against the liberal state classes who had driven the moral assault on workers and peasants. This ushered in the first Kaczynski government (2005-2007), which went under in chaotic symbolic politics and intense infighting. It would depend on the next Hungarian phase of illiberal mobilization for the Polish Right to develop a more coherent program.

The second phase played itself out in the northeastern Hungarian districts. ${ }^{34}$ Instead of labor, it focused on social reproduction. It came into being as a reactionary popular mobilization against what was perhaps the first genuine social democratic government in Hungary and CEE at large (2002-2006), which sought to extend universal social rights at the municipal level in Hungary, including a guaranteed social minimum through family and child benefits and the reintegration of Roma children into mainstream primary education. This was a program explicitly meant to reintegrate the surplus populations. In a context of media-driven moral panics around "gypsy crime," local constituencies rebelled. In their eyes, the social democrats were elevating the undeserving and unemployed Roma to the standards of the Magyar "working poor," from whose taxes the subsidies were paid. They refused to subsidize the social reproduction of large and unruly Roma families and the desegregation of municipal schools. Relative surplus populations were being mobilized against the absolute surplus population. This was nationalist hierarchy in action.

This second phase can be understood, however, only in the context of the weakness of the Hungarian state in relation to global capital. This was the deeper cause behind the failure of the push toward more universalist welfare-statism and the subsequent self-destruction of Hungarian social democracy. Mutual competition meant that CEE states failed to tax capital. The social democratic government in Hungary financed its new politics of social redistribution largely by selling state debt to the financial markets, markets that were flush with liquidity in the early 2000 s. The Hungarian national bank also allowed Swiss franc- and euro-denominated private mortgages with low interest rates (compared to the local currency) to substitute for lacking wage growth. A consumer bonanza was launched with the Hungarian private housing stock as collateral. The social democrats exploited, in other words, the opportunities of transnational finance to make up for the weakness of domestic labor and the state vis-à-vis transnational industrial capital.

What happened next destroyed social democracy in Hungary and opened the gates for an assertive, hierarchy-seeking neo-nationalism. In 2006, with the financial crisis approaching, global investors told the social democrats that new loans would not be forthcoming. Ferenc Gyurcsáni, the prime minister who had just won the 2006 elections from Viktor Orban with his program of universally extended social redistribution, conceded in a leaked post-election speech before his own activists that he had "lied night and day" and that his promises had to be withdrawn immediately. The escalating right-wing rebellion of the working poor against universal welfare in northeastern Hungary now rolled into the streets of 
Budapest. Months of huge and angry mass demonstrations followed, leading to the abdication of Gyurcsáni.

Worse came when the financial crisis broke in the fall of 2008. After 1989, Austrian finance had gradually reoccupied the paramount position in southeastern Europe that it had lost in the crisis of the 1930s. But in late 2008, in the midst of the credit crunch, Viennese financiers panicked. Loans to Hungary and other states had been based on global securitization, not on limited Austrian savings. Austrian bankers feared that the credit crunch would prevent the rollover of those international loans. Outstanding credit to eastern Europe would have to be called in, bankrupting millions of households and states in CEE, or, alternatively, they would have to allow the bankruptcy of the Austrian banks. The rumor alone led to immediate and uncontrolled devaluations of the local currencies, further increasing CEE indebtedness in real terms. Hungary was the largest Austrian liability. The Viennese treasury now intervened by calling in the IMF-an episode not widely reported in the western media-which decided to offer "preventative credits" to CEE states, meant to buffer the local currencies and make a pool of public credit available in case Austrian loans were not to be rolled over. Hungary was offered a twenty-five-billion-dollar credit line, on the order of magnitude of Argentina's state debt (per head).

The then IMF president, the French socialist Dominique Strauss Kahn, explained that old-style IMF conditionality was not on anymore. That turned out not quite to be true. The recently introduced "thirteenth month," which had been the ultimate symbol of "growth" for many workers, was cancelled; health was further privatized; and serious cuts were made in pensions and public salaries. The social democrats were committing nothing less than collective suicide in front of the public. The radical Right Jobbik party and its affiliated Magyar Garda began exploiting small local conflicts in the East to destroy the social democratic base in the eastern provinces, pushing Orban's Fidesz party further to the populist Right. The outcome, in 2010, was the arrival of the most popular radical rightwing government in Europe. It set about using its two-thirds majority in parliament to transform Hungary's rights-based constitution and welfare state into an "illiberal national workfare state." In the process, it attacked the autonomy of the Hungarian National Bank and the Constitutional Court; it renationalized the privatized pension system; it attacked the transnational banking sector, as well as the transnational media and utilities, and forced them (via new taxes and mandated price discounts) to sell out to Hungarian corporations; it nationalized the Budapest stock exchange; and, above all, it created a punitive regime against the Roma and other surplus populations, institutionalizing the Jobbik-driven moral panics of the 2010 s into a permanent zero-tolerance workfare regime. The nation re-created its "natural" ethno-hierarchy, both domestically in the governing of populations and transnationally in the relation to foreign capital. In 2014 it paid off its IMF debt. 
In the third phase, this "illiberal democratic" program was taken over by Law and Justice in Poland, which in October 2015 won the largest electoral victory of any party in Poland since 1989-once again significantly based in the mobilization of its eastern constituencies. Now, with a national-socialist right (stricto sensu) actively creating new illiberal state forms in the two key states of CEE, the Visegrad Bloc began presenting itself as the "eastern scale" within the European Union. For the first time since 1989, it began to speak with a unified political voice, condemning "western-imposed multiculturalism" and confronting the European Union on civil society, human rights, democracy, and immigration, and doing so on behalf of nothing less than the protection of "deserving" domestic labor and for the support of the even more deserving national bourgeoisie and its domestic accumulation.

The contradictions of social reproduction, in particular of working families, until then violently obscured under the mantra of economic growth and "successful transition," returned to haunt the European Union with a vengeance. Cultural hierarchy on behalf of the deserving majority-nation had finally become the new good sense. Internally divided labor, state weakness, dispossession, and disenfranchisement explain why-the multi-scalar narrative presented here as a coda narrates how.

\section{NOTES}

1. Jan Breman and Marcel van der Linden, "Informalizing the Economy: The Return of the Social Question at a Global Level," Development and Change 45, no. 5 (2014): 895-919.

2. Dorothee Bohle and Bela Greskovits, Capitalist Diversity on Europe's Periphery (Ithaca: Cornell University Press, 2012); David Lane and Martin Myant, eds., Varieties of Capitalism in Post-Communist Countries (Basingstoke, U.K.: Palgrave Macmillan, 2007); Peter Hall and David Soskice, eds., Varieties of Capitalism: The Institutional Foundations of Comparative Advantage (Oxford: Oxford University Press, 2001); Bob Hancke, Martin Rhodes, and Mark Thatcher, eds., Beyond Varieties of Capitalism: Conflict, Contradictions, and Complementarities in the European Economy (Oxford: Oxford University Press, 2007).

3. James Ferguson, Give a Man a Fish (Durham, NC: Duke University Press, 2015).

4. Gareth Dale, ed., First the Transition, Then the Crash: Eastern Europe in the 2ooos (London: Pluto, 2011); Srecko Horvat and Igor Stiks, eds., Welcome to the Desert of Post-Socialism: Radical Politics after Yugoslavia (London: Verso, 2015); more ethnographically, see David Kideckel, Getting By in Postsocialist Romania: Labor, the Body, and Working Class Culture (Bloomington: Indiana University Press, 2008).

5. A. Cerami and A. Vanhuysse, eds. Post-Communist Welfare Pathways: Theorizing Social Policy Transformations in Central and Eastern Europe (Basingstoke, U.K.: Palgrave Macmillan, 2009); M. A. Orenstein, "Postcommunist Welfare States," Journal of Democracy 19, no. 4 (2008): 80-94.

6. Bela Greskovits, The Political Economy of Protest and Patience: East European and Latin American Transformations Compared (Budapest: Central European University Press, 1998). Guglielmo Meardi, Social Failures of EU Enlargement: A Case of Workers Voting with Their Feet (London: Routledge, 2011).

7. Alison Stenning, Adrian Smith, Alena Rochovská, and Dariusz Świątek, Domesticating NeoLiberalism: Spaces of Economic Practice and Social Reproduction in Post-Socialist Cities (London: WileyBlackwell, 2010). 
8. David Ost, "Illusory Corporatism Ten Years Later," Warsaw Forum of Economic Sociology 2, no. 1 (2011): 19-49; Stefan Guga, "Fordism in the Periphery," (Phd thesis, Central European University, 2017).

9. Don Kalb, "Conversations with a Polish Populist: Tracing Hidden Histories of Globalization, Class, and Dispossession in Postsocialism (and Beyond)," American Ethnologist 36, no. 2 (2009): 207-23; Don. Kalb, “Worthless Poles' and Other Post-Socialist Dispossessions," in Blood and Fire: Toward a Global Anthropology of Labor, ed. August Carbonella and Sharryn Kashmir, 250-87 (New York: Berghahn Books, 2014).

10. Guga, "Fordism in the Periphery."

11. Gil Eyal, Ivan Szelenyi, and Eleanor Townsley, Making Capitalism without Capitalists: Class Formation and Elite Struggles in Post-Communist Central Europe (London: Verso, (1998); J. Staniszkis, The Dynamics of the Breakthrough in Eastern Europe: The Polish Experience (Berkeley: University of California Press, 1991).

12. A good example is Vladimir Tismaneanu, Fantasies of Salvation: Democracy, Nationalism, and Myth in Post-Communist Europe (Princeton, NJ: Princeton University Press, 2009).

13. Michal Buchowski, "The Specter of Orientalism in Europe: From Exotic Other to Stigmatized Brother," Anthropological Quarterly 79, no. 3 (2006): 463-82.

14. Don Kalb, "Regimes of Value and Worthlessness: How Two Subaltern Stories Speak," in Work and Livelihoods, ed. Victoria Goddard and Susana Narotzky, 123-36 (London: Routledge, 2016).

15. David Ost, The Defeat of Solidarity: Anger and Politics in Postcommunist Europe (Ithaca: Cornell University Press, 2005).

16. Michael Burawoy, The Politics of Production: Factory Regimes under Capitalism and Socialism (London: Verso, 1985); Katherine Verdery, What Was Socialism and What Comes Next? (Berkeley: University of California Press, 1996).

17. Eszter Bartha, Alienating Labour: Workers on the Road from Socialism to Capitalism in East Germany and Hungary (New York: Berghahn Books, 2013); Alina-Sandra Cucu, Planning Labour: Time and the Foundations of Industrial Socialism in Romania (Oxford: Berghahn Books, 2019).

18. Ivan Szelenyi, Urban Inequalities under State Socialism (Oxford: Oxford University Press, 1983).

19. Martin Myant and Jan Drahokoupil, Transition Economies: Political Economy in Russia, Eastern Europe, and Central Asia (London: Wiley, 2010). Bohle and Greskovits, Capitalist Diversity on Europe's Periphery; S. Haggard and R. R. Kaufman, "The Eastern European Welfare State in Comparative Welfare State," In Post-Communist Welfare Pathways: Theorizing Social Policy Transformations in Central and Eastern Europe, ed. A. Cerami and A. Vanhuysse, 217-36 (Basingstoke, U.K.: Palgrave Macmillan, 2009); Cristiano Perugini and Fabrizio Pompei, eds., Inequalities During and After Transition in Central and Eastern Europe (London: Palgrave Macmillan, 2015).

20. Bela Greskovits, The Political Economy of Protest and Patience: East European and Latin American Transformations Compared (Budapest: Central European University Press, 1998).

21. Guglielmo Meardi, Social Failures of EU Enlargement: A Case of Workers Voting with Their Feet (London: Routledge, 2011).

22. Jan Drahokoupil, Globalization and the State in Central and Eastern Europe: The Politics of Foreign Direct Investment (London: Routledge, 2008); Bob Jessop, The Future of the Capitalist State (Cambridge: Polity Press, 2002).

23. Cerami and Vanhuysse, Post-Communist Welfare Pathways.

24. Linda Cook, "More Rights, Less Power: Labor Standards and Labor Markets in East European Post-communist States," Studies in Comparative International Development 45 (2010): 170-97.

25. Gabor Scheiring, "The Political Economy of Democratic Backsliding" (paper presented at a conference of the European Sociological Association, Prague, 2015).

26. Göran Therborn, "New Masses? Social Bases of Resistance," New Left Review 85 (2014): 7-16.

27. K. Polanyi, The Great Transformation: The Political and Economic Origins of Our Time (Boston, MA: Beacon Press, 2001), originally published 1944. 
28. See also K. E. Friedman and J. Friedman, Modernities, Class, and the Contradictions of Globalization: The Anthropology of Global Systems (Lanham: Altamira Press, 2008); K. E. Friedman and J. Friedman, Historical Transformations: The Anthropology of Global Systems (Lanham: Altamira Press, 2008).

29. Nicolette Makovicky, “'Work Pays': Slovak Neoliberalism as 'Authoritarian Populism," Focaal: Journal of Global and Historical Anthropology 67 (2013): 77-90; Cristina Rat, "The Impact of Minimum Income Guarantee Schemes in Central and Eastern Europe," in Post-Communist Welfare Pathways: Theorizing Social Policy Transformations in Central and Eastern Europe, ed. A. Cerami and A. Vanhuysse, 217-36 (Basingstoke, U.K.: Palgrave Macmillan, 2009).

30. Eeva Keskula, "Reverse, Restore, Repeat! Class, Ethnicity, and the Russian-Speaking Miners of Estonia," Focaal: Journal of Global and Historical Anthropology 72 (2015): 95-108.

31. Georgi Medarov, "Is Liberal Populism Possible?" (paper presented at the conference "The Sources of Populism in the Balkans," Marija Bistrica, October 2014).

32. Don Kalb, "Upscaling Illiberalism: Class, Contradiction, and the Rise and Rise of the Populist Right in Post-Socialist Central Europe," Fudan Journal of the Humanities and the Social Sciences 11 (2018): 323-39; Gabor Halmai, "(Dis)possessed by the Specter of Socialism: Nationalist Mobilization in 'Transitional' Hungary," in Headlines of Nation, Subtexts of Class: Working-Class Populism and the Return of the Repressed in Neoliberal Europe, ed. Don Kalb and Gabor Halmai, 113-41 (New York: Berghahn Books, 2011); Kristof Szombati, The Revolt of the Provinces: Anti-Gypsyism and Right-Wing Politics in Hungary (New York: Berghahn Books, 2018).

33. For a more complete discussion, see Kalb, "Upscaling Illiberalism."

34. Szombati, The Revolt of the Provinces. 